\title{
Identification of internal defects of hardfacing coatings in regeneration of machine parts
}

\author{
Jerzy Józwik ${ }^{1, *}$, Krzysztof Dziedzic ${ }^{2}$, Mykhalo Pashechko ${ }^{3}$, and Andrzej Łukasiewicz ${ }^{4}$ \\ ${ }^{1}$ Lublin University of Technology, Mechanical Engineering Faculty, Department of Production Engineering, 36 Nadbystrzycka \\ Street, 20-816 Lublin, Poland \\ ${ }^{2}$ Lublin University of Technology, Electrical Engineering and Computer Science Faculty, Institute of Computer Science, \\ 20-618 Lublin, Nadbystrzycka 36B, Poland \\ ${ }^{3}$ Fundamentals of Technology Faculty, Lublin University of Technology, 38 Nadbystrzycka Street, 20-618 Lublin, Poland \\ ${ }^{4}$ POLFER Podzespoły Indukcyjne S.A., 25 Woźniki, 08-200 Łosice, Quality Department, Poland
}

\begin{abstract}
The quality control of hardfacing is one of the areas where non-destructive testing is applied. To detect defects and inconsistencies in the industrial practice one uses the same methods as in the testing of welded joints. Computed Tomography is a type of X-ray spectroscopy. It is used as a diagnostic method that allows to obtain layered images of examined hardfacing. The paper presents the use of Computed Tomography for the evaluation of defects of hardfacing parts and errors. Padding welds were produced using GMA consumable electrode welding with $\mathrm{CO}_{2}$ active gas. The padding material used were cored wires FILTUB DUR 16, and ones produced from a Fe-Mn-C-Si-Cr-Mo-Ti-W alloy. The layers were padded on to different surfaces: C45, 165CrV12, 42CrMo4, S235JR steel. Typical defects occurring in the pads and the influence of the type of wire on the concentration of defects were characterized. The resulting pads were characterized by occurring inconsistencies taking the form of pores, intrusions and fractures.
\end{abstract}

\section{Introduction}

The main reason of machine part defects which cause, already high, costs incurred by companies to rise, is wearing of work surfaces. Currently, one of the most used methods of regenerating machine parts is using hardfacing, i.e. the layering of liquid metal onto the object being regenerated [1-2]. In comparison to welding, hardfacing is not a process of joining elements, but one aiming to create a surface layer on the object, of a material supplied usually using an electrode or a wire. Often, hardfacing is used for regeneration, repairs or modernization elements of tools and machines, the replacement of which would usually be too work or cost intensive. At Polfer Podzespoły Indukcyjne S.A., injection molds are being repaired using this method. The wear caused by the form being burned out or by cracked edges on the elements forming the object, lead to flashes being produced, which can cause the product to be rejected at later stages of processing. Scrapping an injection form is economically unreasonable. Other methods of repairing a worn tool which include cutting out the offending fragment, manufacturing and mounting a compensating one, are often costly and very difficult, if not impossible. In those cases, hardfacing and processing the worn element is quite reasonable, economically and technically. However, situations do occur, in which a defect in the hardface can cause the surface of the form, after the aforementioned repair work has been carried out, to become worn quickly, local irregularities or pits to appear. Those are visible on the surface of the product after injection, as localized micro-flashes. Therefore, detecting and dealing with defects in hardfacing is quite important in industrial practice.

Positive technical and economic effects of regenerating and modifying surfaces using the hardfacing method, in particular regard to elements, which require high resistance to wear, and corrosion, caused the dynamic development of technologies, tools and materials used for hardfacing. The welding techniques being used currently allow for repairs to be carried on practically every damaged or worn part, by way of welding or hardfacing. Some of the most modern and most often used hardfacing materials are electrodes, or solid and cored wires. The materials used currently are produced from $\mathrm{Fe}, \mathrm{Ni}, \mathrm{Co}, \mathrm{Ti}$ with additions of different elements; among others: $\mathrm{Si}, \mathrm{Cr}, \mathrm{B}, \mathrm{Mn}, \mathrm{V}, \mathrm{Mo}$, $\mathrm{W}, \mathrm{Nb}$, which influence the mechanical, tribological and corrosive properties of these materials [2-7].

In industrial practice, detecting defects and inconsistencies in faced layers, is done using the same methods as the ones used in studying welded joints.

Modern computer tomography, with its advantages, is steadily rising in availability and usage in industrial applications, including welding. Computer Tomography (CT) is a type of $\mathrm{x}$-ray spectroscopy. It is used a diagnostic method, allowing the user to obtain images of the layers of the faces being studied [8-11]. It utilizes

\footnotetext{
Corresponding author: e-mail: j.jozwik@pollub.pl
} 
a composite projection of the object, produced from images taken from different directions to create section (2D) and spatial (3D) images [12]. In relation to the above, computer tomography has been used in welding for non-invasive studies of welded joints and hardfaces. The aim of these studies is to determine the qualitative and quantitative occurrence of welding defects, their spacing and sizes [13]. CT is more accurate method when compared to the Roentgen methods used previously. It is however limited by high equipment cost, mobility and the size of the measurement surface [14$18]$.

\section{Materials and methods}

\subsection{Hardfacing coatings}

The subject of the study was hardfaced coatings. These coats ere made using GMA arc hardfacing with $\mathrm{CO}_{2}$, with the wire being fed manually. The hardfacing was conducted using the ESAB POWER COMPACT 250 welding device. To ensure identical facing conditions, all processes were conducted using one type of shielding gas $\left(\mathrm{CO}_{2}\right)$; the other facing parameters were also unchanged for all other samples (Fig. 1).

The following parameters were used for facing:

- amperage: $230 \mathrm{~A}$

- $\quad$ welding power: $\mathrm{DC}+$

- $\quad$ wire feed speed : $7 \mathrm{~m} / \mathrm{min}$

In industrial practice, a common occurrence is the need to repair or regenerates parts of machines produced from different materials. Quite often, these materials are classified as difficult or impossible to weld, such as: 165CRV12 and 42CrMo4 steel. To check if such elements can be fixed or regenerated, with the use of cored wires being studies in this work, samples have been obtained by hardfacing different types of steel, starting with typical weldable steels, f.ex. C45 or S235JR, and ending with those marked as impossible to weld, 165CRV12 and 42CrMo4. For comparison purposes, the hardfacing was done using two different cored wires, intended for that process. The cored wires used, were FILTUB DUR 16 (trade name) and a $\varnothing 1,2$ $\mathrm{mm}$ diameter wire marked as $\mathrm{N}-4$, produced from the Fe$\mathrm{Mn}-\mathrm{C}-\mathrm{Si}$-Cr-Mo-Ti-W alloy. The chemical composition of the cored wires used for hardfacing can be found in Table 1 .

Table 1. Chemical composition (w \%) of the cored wires being used (FILTUB DUR 16 and N-4).

\begin{tabular}{|c|c|c|c|c|c|c|c|}
\hline \multicolumn{7}{|c|}{ Element (wt. \%) } \\
\hline & C & Si & Mn & Cr & Mo & W & Ti \\
\hline $\begin{array}{c}\text { FILT } \\
\text { UB } \\
\text { DUR } \\
16\end{array}$ & 0.45 & 0.60 & 1.6 & 5.5 & 0.8 & - & - \\
\hline N-4 & 0.98 & 0.89 & 2.05 & 5.57 & 1.92 & 2.29 & 0.97 \\
\hline
\end{tabular}

The FILTUB DUR 16 wire is an alkaline, intermediate alloy cored wire used for hardfacing coats resistant to grinding wear on elements such as: grabs of a digger, teeth of scoop, jaws, hammers, mixer blades, etc.). The cored wire produced from the Fe-Mn-C-Si-CrMo-Ti-W alloy, is used for hardfacing coats resistant to grinding wear.

The coats were faced onto different surfaces, such as:

- C45 carbon steel - used in the production of machine bodies, form for processing plastics. It also used in the production of support elements of tools, such as: plates, spacers, etc. It is characterized by high strength and ductility.

- $165 \mathrm{CrV} 12$ steel (NC10) - a ledeburite chrome steel, intended, among others, for threading tools, high efficiency cutting tools, forming rollers, wire drawing dies, steel cutting knives. A steel characterized by a low tendency to crack.

- $42 \mathrm{CrMo} 4$ steel - heat enhancement steel with high hardenability. It is characterized by a high resistance to grinding wear. Used in the production of machine elements which require high strength and ductility, such as: turbine parts, cogs, rotors, shafts, pipe joints.

- S235JR steel - used in welded constructions. Utilized in support structures, as well as those carrying dynamic loads, such as: crane pillars, bodies of ore processing machines, heavily loaded bridges, pulleys.
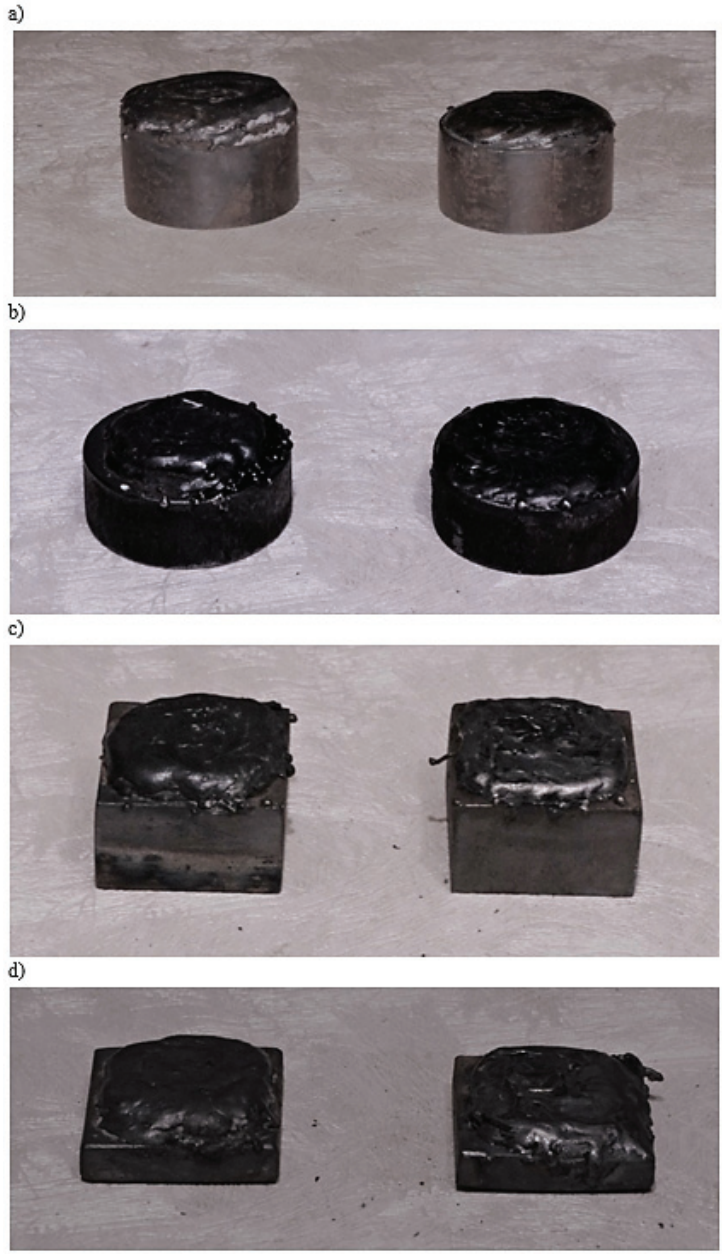

Fig. 1. Samples faced using cored wired marked as N4 (left side) and FILTUB DUR 16 (right side), on: a) C45, b) $165 \mathrm{CrV} 12$, c) 42CrMo4, d) S235JR steel. 
Welding was conducted down hand. Faces were layered spirally, in two layers, clockwise, starting from the center of the sample. Manually feeding the wire is characterized characterizes itself by relatively low thickness of the whole area being faced. The thickness of the faces being layered on in a single passes was, on average, $3 \mathrm{~mm}$. The second layer was applied after a period of time required to remove the carbon deposits left, after applying the first layer.

The faced samples can be seen in Fig. 1. The samples were processed mechanically by grinding and electric discharge cutting, to appropriately correct and align their shape and size (diameter: $33.5 \mathrm{~mm}$, height: 10 $\mathrm{mm}$ ). The grinding process has been carried on a KENT surface grinder.

\subsection{Microtomographic identification of defects in hardfaced layers}

The inconsistencies in structure and internal defects has been carried out using an X25 (North Star Imaging) computer tomography machine, shown in Fig. 2. Source of x-ray radiation: Hamamatsu L12161-07 (voltage: 50 $\mathrm{kV}$, current: $200 \mu \mathrm{A}$, focal spot size: 20 microns), detector - Varian (pixel pitch: 127 x 127 microns, mode: 01 1x10.5pFVG1 framerate: 10 fps. flip: none, rotation: 90 degree), Distances (tube to detector: $1014.228 \mathrm{~mm}$, tube to part: $348.689 \mathrm{~mm}$, calculated Ug: $0.03817 \mathrm{~mm}$, zoom factor: $\times 2.91$. The study consisted of directing an $\mathrm{x}$-ray at the object, and registering the radiation intensity on the other side of the detector panel. All hardfaced samples have been exposed in identical conditions.

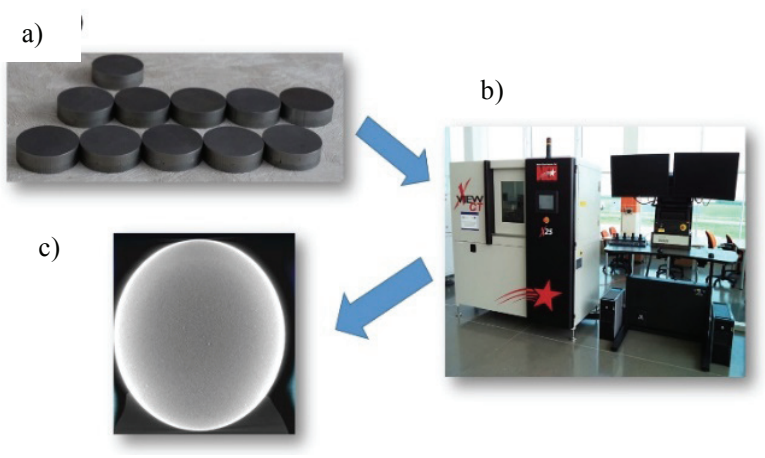

Fig. 2. Images from the study: a) samples after mechanical processing, b) X25 (North Star Imaging) computer tomography system, c) X-Ray image of the face.

\section{Results and discussion}

Samples, the base material of which was C145 steel, were faced using FILTUB DUR 16 cored wire. These did not show any defects, in the form of "white grains", which are areas of reduced radiation permeability. No scratches or cracks were observed either. The only defects were a few areas of slightly reduced density (Fig. 3). The size of these areas did not exceed $2 \mathrm{~mm}$.

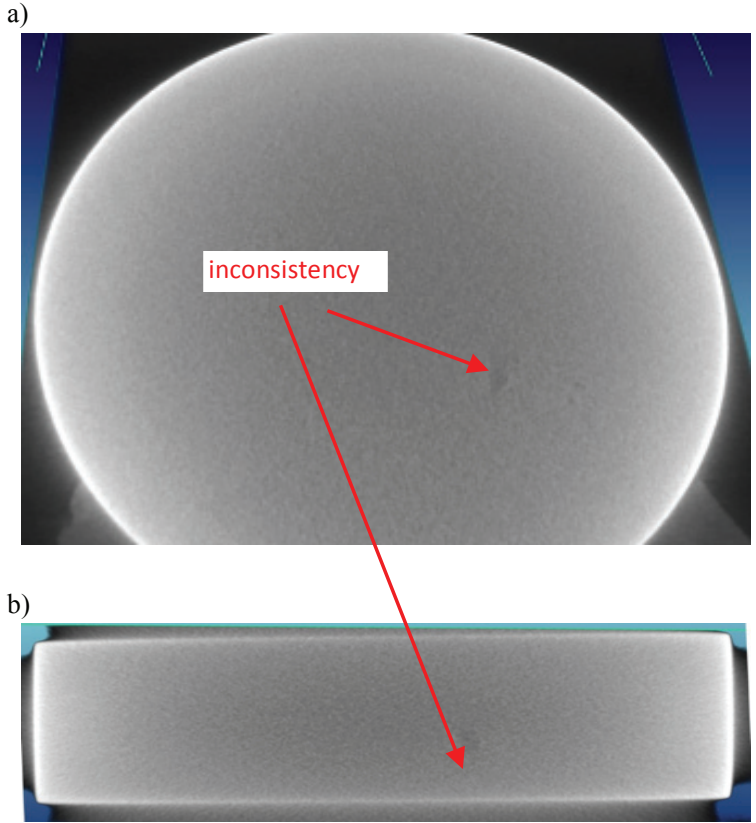

Fig. 3. Sample faced with FILTUB DUR 16 cored wire on C45 steel: a) horizontal cross-section (front view), b) vertical crosssection.

In the case of samples, the base material of which was C45 steel, faced with N4 cored wire, very slight intrusions can been seen on the whole surface of the face (Fig. 4).

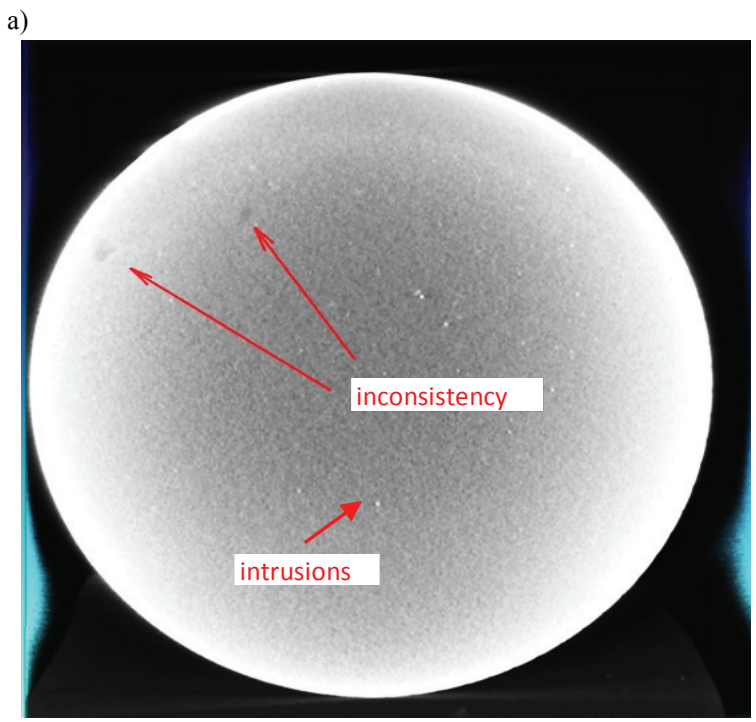

b)

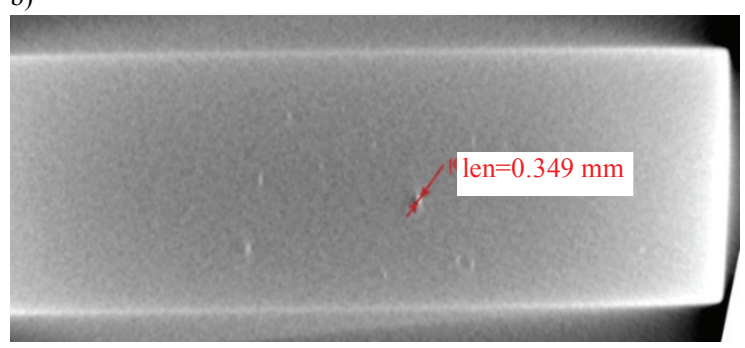

Fig. 4. Sample faced with N-4 cored wire on C45 steel: a) horizontal cross-section (front view), b) vertical crosssection. 
These intrusions show up on the image as significantly brighter than the surrounding material. This is evidence of their higher density and significantly higher x-ray radiation absorption. The largest observed intrusion had a diameter of less than $0.4 \mathrm{~mm}$. No signs of a layered structure were observed, which indicates proper melting of the base material during facing. However, individual small, darker areas have been observed, which indicates the presence of inconsistencies, such as air bubbles.

Similarly to samples on a C45 steel base, 165CRV12 (NC10) based samples faced with FILTUB DUR 16 cored wire did not exhibit any of the following defects: scratches, cracks or grains of a significant size and radiation permeability (Fig. 5). Defects consisting of areas of reduced density were rare and small. The largest face structure inconsistencies observed were smaller than $1.5 \mathrm{~mm}$.

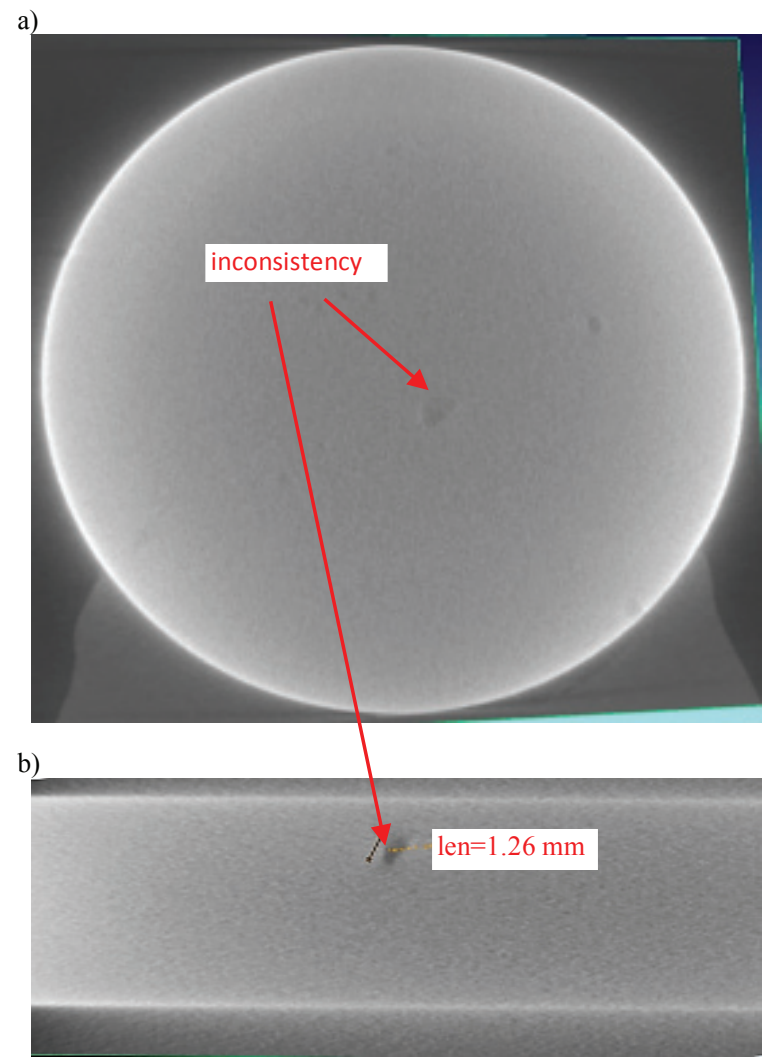

Fig. 5. Sample faced with FILTUB DUR 16 cored wire on 165 rV12 steel: a) horizontal cross-section (front view), b) vertical cross-section.

In samples faced with N-4 cored wire, on a $165 \mathrm{CrV} 12$ steel, one can observe (similarly to C45 steel) very slightly, significantly large intrusion, absorbing X-rays, as well as intrusions with inconsistent distribution (Fig. 6). Layered structures have not been found. A smaller amount of lower density areas has been observed, however they were larger. The largest inconsistency area measured: $0.981 \times 1.72 \mathrm{~mm}$.

Also visible are scratches and cracks. The largest crack measure $8.97 \mathrm{~mm}$ in length and $0.243 \mathrm{~mm}$ in width. The largest crack was $0.563 \mathrm{~mm}$ deep. The base material remained untouched.
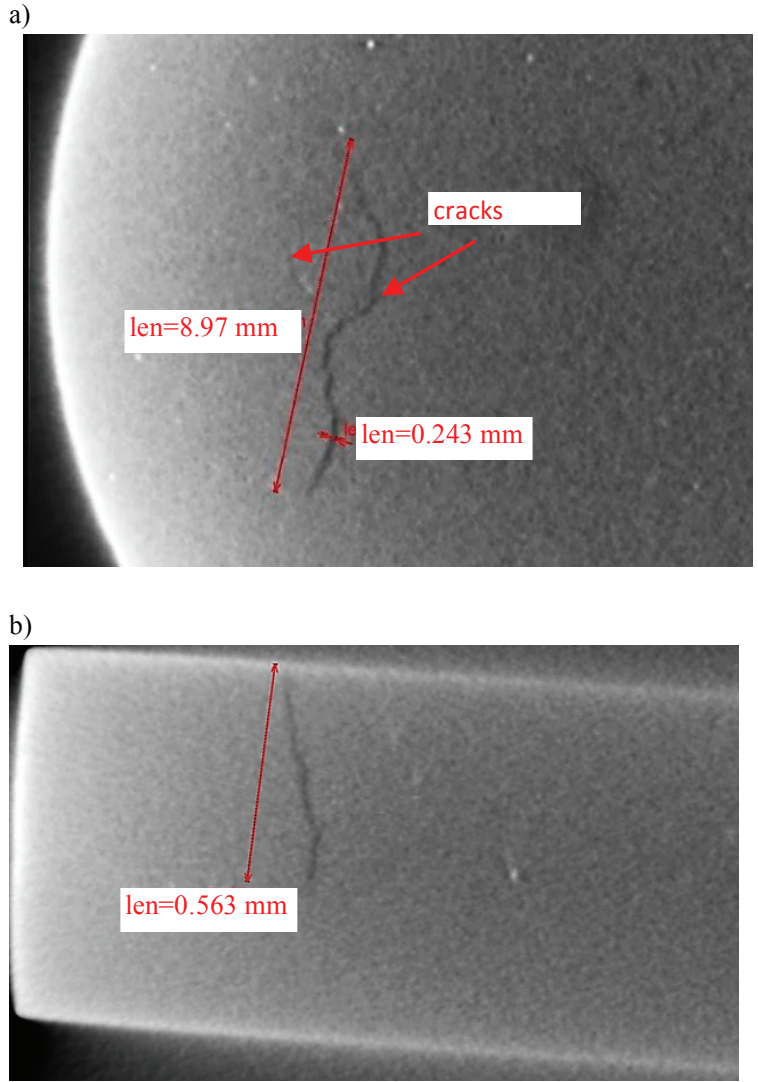

Fig. 6. Sample faced with N-4 cored wire on $165 \mathrm{CrV} 12$ steel: a) horizontal cross-section (front view), b) vertical crosssection.

Samples faced using FILTUB DUR 16 cored wired (base material 142CrMo4), do not exhibit any visible defects (Fig. 7).

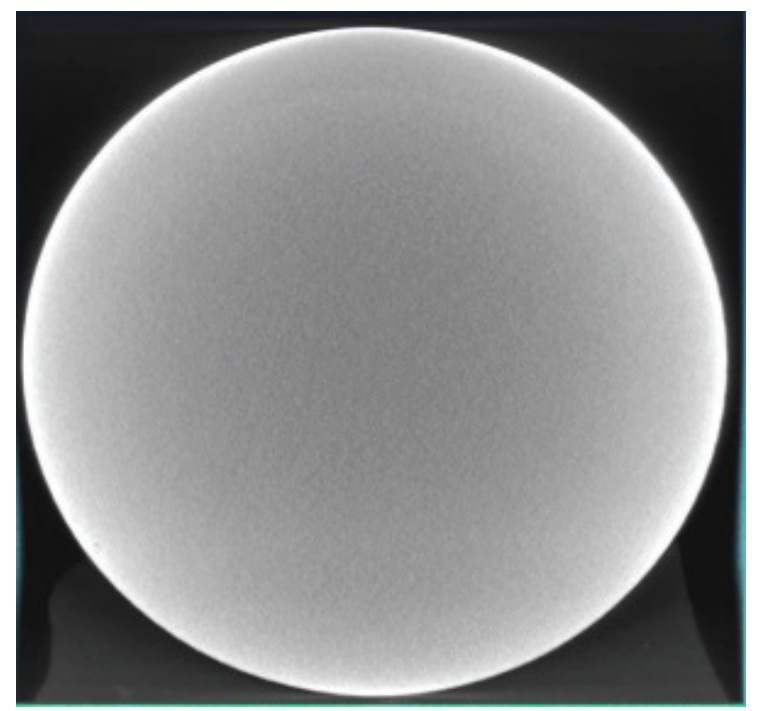

Fig. 7. Sample faced with FILTUB DUR 16 cored wire on $42 \mathrm{CrMo} 4$ steel- horizontal cross-section (front view).

The samples faced using N-4 cored wire on $42 \mathrm{CrMo} 4$ base are characterized by small, irregularly spaced intrusions, characterized by high density and low X-ray permeability appearing in the face, as well as smaller areas of much lower density, identified as air bubbles. 
The sizes and charcteristics of these defects is similar to those on $165 \mathrm{CrV} 12$ steel. In the case of $42 \mathrm{CrMo} 4$ steel, these cracks appear in larger numbers, and are of similar size when compare to those on $165 \mathrm{CrV} 12$ steel. These cracks can be as deep as the whole face, in both layers (Fig. 8). However, they are less visible and narrower (about $0.1 \mathrm{~mm}$ wide).

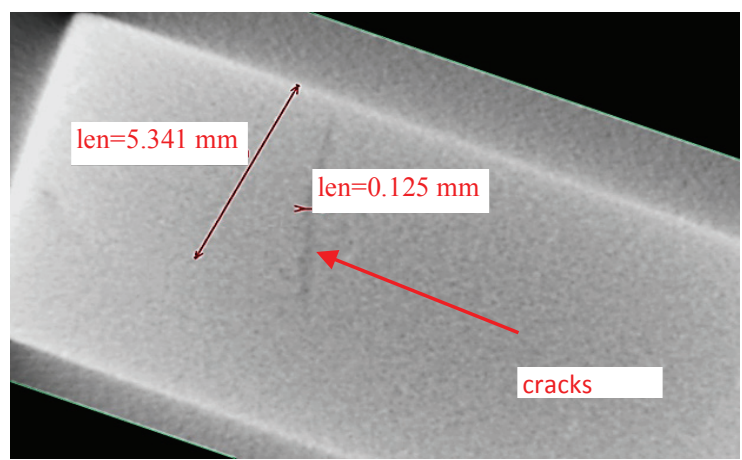

Fig. 8. Sample faced with M-4 cored wire on $42 \mathrm{CrMo} 4$ steelvertical cross-section.

Similar to all previous samples faced with FILTUB DUR 16 cored wire, the sample with a S235JR steel base does not exhibit any defects manifesting as small areas with very high density. No cracks or scratches are visible either.

However, the area of reduced density can be observed in all areas of the sample, located at a depth corresponding to the first layer of the hardface (Fig. 9).

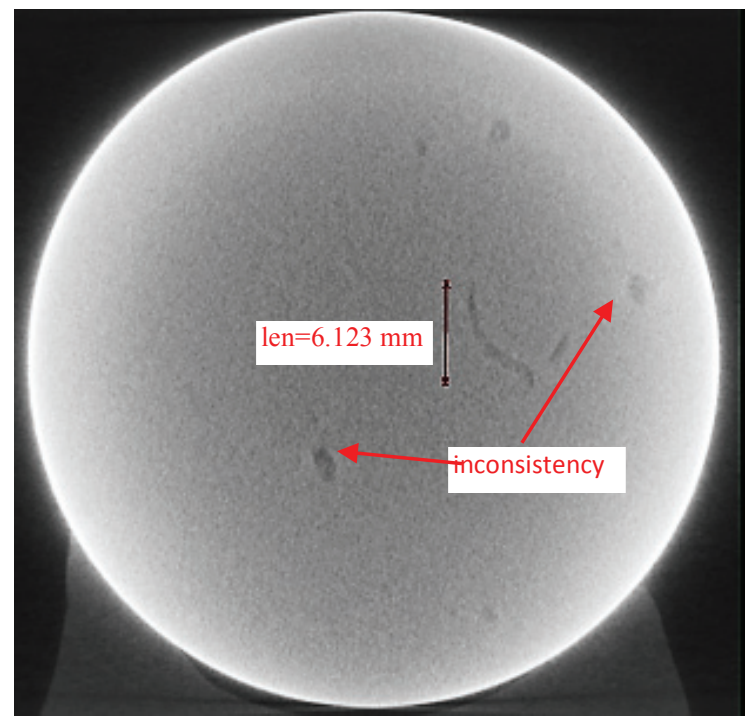

Fig. 9. Sample faced with FILTUB DUR 16 cored wire on S 235 JR steel.

As with all samples faced with N4 wire, the samples with S235JR steel exhibit very small intrusion spaced irregularly along the whole mass of the face, characterized by small X-ray permeability, visible in photographs as very small, white grains.

Reduced density defects were also observed. They occur at a depth corresponding to the first hardface layer. Largest horizontal cross-sections: 1.465 × $7.369 \mathrm{~mm}$ (Fig. 10)

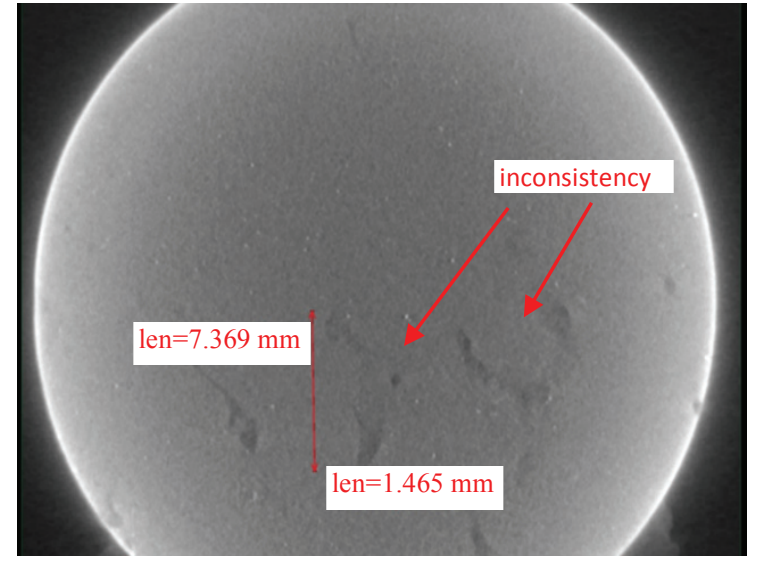

Fig. 10.. Sample faced with N-4 cored wire on S 235 JR steel.

A compilation of analysis results for the studied samples can be found in Table 2. The analysis showed, that less defects were found in the faced layers when using FILTUB DUR 16 cored wired. In regards to the N4 wire: modifying the hardfacing process was recommended in most cases.

Table 2. Compilation of analysis results for the studied samples.

\begin{tabular}{|c|c|c|}
\hline $\begin{array}{c}\text { Face/ } \\
\text { Base }\end{array}$ & $\begin{array}{c}\text { Types of exhibited } \\
\text { defects }\end{array}$ & Notes \\
\hline $\begin{array}{c}\text { FILTUB DUR 16/ } \\
\text { C45 }\end{array}$ & $\begin{array}{c}\text { Individual bubbles in the } \\
\text { first hardface layer }\end{array}$ & $\begin{array}{c}\text { Decision to be } \\
\text { made dependent } \\
\text { on intended use }\end{array}$ \\
\hline $\begin{array}{c}\text { N-4/ } 45 \\
\text { FILTUB DUR 16/ } \\
\text { 165CrV12 }\end{array}$ & $\begin{array}{c}\text { Individual bubbles in the } \\
\text { intrusions. }\end{array}$ & $\begin{array}{c}\text { first hardface layer } \\
\text { made dependent } \\
\text { on intended use }\end{array}$ \\
\hline $\begin{array}{c}\text { Decision to be } \\
\text { m-4/ } \\
\text { on intendendent use }\end{array}$ \\
\hline $\begin{array}{c}\text { 165CrV12 } \\
\text { FILTUB DUR 16/ } \\
\text { 42CrMo4 }\end{array}$ & $\begin{array}{c}\text { Grains of unidentified } \\
\text { intrusions. Cracks }\end{array}$ & $\begin{array}{c}\text { Process } \\
\text { modification } \\
\text { recommended }\end{array}$ \\
\hline $\begin{array}{c}\text { N-4/ } \\
\text { 42CrMo4 }\end{array}$ & $\begin{array}{c}\text { Grains of unidentified } \\
\text { intrusions. Cracks }\end{array}$ & $\begin{array}{c}\text { Process } \\
\text { modification } \\
\text { recommended }\end{array}$ \\
\hline $\begin{array}{c}\text { FILTUB DUR 16/ } \\
\text { S 235JR }\end{array}$ & $\begin{array}{c}\text { Groups of bubbles in the } \\
\text { first hardface layer }\end{array}$ & $\begin{array}{c}\text { Process } \\
\text { modification } \\
\text { recommended }\end{array}$ \\
\hline $\begin{array}{c}\text { N-4/ } \\
\text { S 235JR }\end{array}$ & $\begin{array}{c}\text { Grains of unidentified } \\
\text { intrusions. Groups of } \\
\text { bubbles in the first } \\
\text { hardface layer }\end{array}$ & $\begin{array}{c}\text { Process } \\
\text { modification } \\
\text { recommended }\end{array}$ \\
\hline
\end{tabular}

\section{Conclusions}

On the basis of the carried out research the following conclusions have been formulated:

- The computer tomography method described in this paper offers a significantly better process of diagnostics and controlling of hardfaced layers and welded joints when compared to rational radiography.

- CT allows for better accuracy when detecting 
welding defects, which allows the user to evaluate the hardfaces and determine their operative usability.

- All hardfaces produced on samples using FILTBU DUR 16 cored wires exhibit inconsistencies in the form of pores. All of the faces did not exhibit any cracks.

- All hardfaces produced on samples using N4 cored wires exhibit small, high density intrusions of an unidentified material. The intrusions are visible as white grains on the grey background on the face.

- Hardfaces produced on samples using N4 cored wires on $165 \mathrm{CrV} 12$ and $42 \mathrm{CrMo} 4$ wires, identified as difficult to weld exhibit multiple cracks. A solution to this problem can be a modification of the process, i.e. changing hardfacing parameters, using a buffer layer or heating the base material.

\section{References}

1. R. Kolbusz, A. Tabor, W. Wojciechowski, AFE 6, 21 (2006)

2. M. Pashechko, K. Dziedzic, M. Barszcz, Powder Metall. Met. Ceram. 52, 7-8 (2013)

3. J. Józwik, K. Dziedzic, I. Usydus, P. Raos, G. Krolczyk, Teh. Vjesn. 5, 23 (2016)

4. N. Yüksel, S. Sahin, Mater. Des. 58 (2014)

5. E. Badisch, C. Katsich, H. Winkelmann, F. Franek, R. Manish, Tribol. Int. 43 (2010)

6. R. Kumar, S. Chattopadhyaya, S. Hloch, G. Krolczyk, S. Legutko, Eksploatacja i Niezawodnosc - Maintenance and Reliability 18, 1 (2016)

7. M. Tabatabaeipour, J. Hettler, S. Delrue, K. Abeele, NDT\&E International 80 (2016)

8. E. Ratajczyk, Pomiary Automatyka Robotyka 5 (2012)

9. S. K. Dinda, J. M. Warnett, M. A. Williams, G. Roya, P. Srirangam, Mater. Des. 96 (2016)

10. J.B. Krolczyk, B. Gapinski, G.M. Krolczyk, I. Samardzic, R.W. Maruda, K. Soucek, Y. Javadi, S. Legutko, P. Nieslony, L. Stas, Teh. Vjesn. 23 (1) (2016)

11. J. Zapata, R. Vilar, R. Ruiz, Expert Syst. Appl. 38 (2011)

12. M. Yang, S.M. Xiong, Z. Guo, Acta Materialia 92 (2015)

13. U. Hampel, A volume in Woodhead Publishing Series in Electronic and Optical Materials (2015)

14. A. Kułaszka, M. Chalimoniuk, M. Wieczorowski, D. Brzozowski, Przegląd Spawalnictwa 12 (2015)

15. J. Józwik, K. Dziedzic, W. Wierzba, Przegląd spawalnictwa 88, 7 (2016)

16. J. Jozwik, M. Czwarnowski, ASTRJ 9, 28 (2015)

17. J. Jozwik, L. Semotiuk, I. Kuric, ASTRJ 9, 28 (2015)

18. G. M. Krolczyk, J. B. Krolczyk, R. W. Maruda, S. Legutko, M. Tomaszewski, MEAS 88 (2016) 